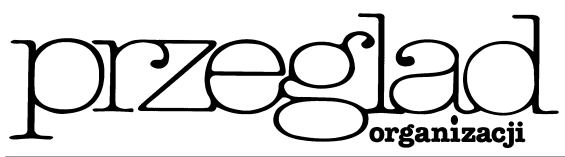

\title{
Kierunki i trendy restrukturyzacji przedsiębiorstw przemysłu obronnego w Stanach Zjednoczonych i Europie Zachodniej
}

https://doi.org/10.33141/po.2005.06.08

Andrzej Lis
Przegląd Organizacji, Nr 6 (785), 2005, ss. 33-37 www.przegladorganizacji.pl Towarzystwo Naukowe Organizacji i Kierownictwa (TNOiK)

\section{Uwagi wstępne}

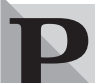
rzemysł obronny należy do sektorów podlegających intensywnym i głębokim procesom restrukturyzacyjnym. Burzliwe zmiany $\mathrm{w}$ otoczeniu organizacyjnym przedsiębiorstw tego sektora, jakie miały miejsce na przełomie lat 80. i 90. XX wieku (zakończenie „zimnej wojny”, procesy rozbrojeniowe i ograniczenie wydatków na cele wojskowe, a w efekcie spadek popytu na uzbrojenie i sprzęt wojskowy), zdeterminowały podejmowanie przez liczne firmy procesów restrukturyzacyjnych. Sytuacja ta dotyczy przemysłu obronnego w większości państw na świecie, w tym głównych producentów uzbrojenia i sprzętu wojskowego, począwszy od firm ze Stanów Zjednoczonych, poprzez przedsiębiorstwa zachodnioeuropejskie i rosyjski kompleks przemysłowo-wojskowy. Głębokie zmiany restrukturyzacyjne w obrębie przemysłu obronnego wystąiły także w państwach Europy Środkowo-Wschodniej, gdzie sytuacja przedsiębiorstw sektora dodatkowo została skomplikowana przez zerwanie więzi kooperacyjnych i handlowych, funkcjonujących w ramach Układu Warszawskiego i Rady Wzajemnej Pomocy Gospodarczej. Również w Polsce, od początku lat 90. ubiegłego wieku, opracowywane są rządowe plany makrorestrukturyzacji sektora obronnego, a przedsiębiorstwa polskiego przemysłowego potencjału obronnego wdrażają wewnętrzne programy restrukturyzacyjne ${ }^{1)}$.

Transformacja gospodarcza, integracja Polski ze strukturami euroatlantyckimi oraz wdrażane programy modernizacji technicznej Sił Zbrojnych RP i restrukturyzacji przemysłowego potencjału obronnego spowodowały, że przedsiębiorstwa sektora w coraz większym stopniu podejmują współpracę z firmami zagranicznymi, w tym głównie z partnerami z państw Europy Zachodniej i Stanów Zjednoczonych. Procesy restrukturyzacji przedsiębiorstw polskiego przemysłowego potencjału obronnego mogą w przyszłości podlegać trendom restrukturyzacyjnym, jakie mają miejsce w przemyśle obronnym w tych państwach. Stąd też, w kontekście restrukturyzacji przedsiębiorstw polskiego przemysłowego potencjału obronnego, nie- zwykle istotne wydaje się dokonanie analizy kierunków i trendów procesów restrukturyzacyjnych przedsiębiorstw przemysłu obronnego na świecie, a zwłaszcza w Stanach Zjednoczonych i Europie Zachodniej.

Zgodnie z przyjętym w rozwiniętych gospodarkach rynkowych sposobem postrzegania istoty restrukturyzacji przedsiębiorstwa może ona obejmować „...szeroki zakres transakcji, włączając w to sprzedaż części firmy (divestitures of lines of business), czy pozyskanie nowych dziedzin działalności (acquisitions), zmianę struktury kapitałowej przez zwiększenie poziomu zadłużenia czy zmianę wewnętrznej organizacji firmy"2). Uwzględniając powyższy zakres pojęciowy restrukturyzacji przedsiębiorstwa, na podstawie analizy literatury przedmiotu, dokonano próby identyfikacji głównych kierunków i trendów w restrukturyzacji przedsiębiorstw przemysłu obronnego na świecie, zaliczając do nich $^{3)}$ :

- koncentrację kapitału i konsolidację przedsiębiorstw,

- rozwój współpracy międzynarodowej,

- prywatyzację,

- zmiany w strukturze prac badawczych i produkcji.

\section{Konsolidacja przedsiębiorstw}

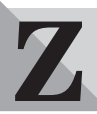

jawisko koncentracji kapitału oraz konsolidacji przedsiębiorstw przemysłu obronnego na świecie sięga lat 70 . XX wieku. Przyczyn koncentracji kapitału i konsolidacji produkcji specjalnej należy upatrywać $\mathrm{m}$.in. $\mathrm{w}^{4)}$ :

- szybkim wzroście kosztów rozwoju i produkcji kolejnych generacji uzbrojenia i sprzętu wojskowego (UiSW);

- rosnącym zaawansowaniu technologicznym produkcji specjalnej, co wymagało wyspecjalizowanego parku maszynowego oraz wysoko kwalifikowanej siły roboczej;

- wzroście ryzyka niepowodzenia przedsięwzięć związanych z wytwarzaniem uzbrojenia, wynikającym ze spadku zapotrzebowania na wyroby specjalne przy równoczesnym szybkim wzroście kosztów badań i produkcji; 
- rosnących trudnościach z wejściem i utrzymaniem się na coraz mniejszym rynku uzbrojenia i sprzętu wojskowego.

Mimo że przemysł obronny charakteryzuje się znacznie mniejszym stopniem koncentracji niż przemysły wysokiej technologii produkujące na rynki cywilne, w okresie po 1990 roku, w jego obrębie wystapił znaczny wzrost poziomu koncentracji produkcji. Dynamika procesu koncentracji, niezbyt wysoka w pierwszej połowie lat 90., uległa przyspieszeniu w latach 1995-2000. Wzrastająca koncentracja skutkowała rozwojem przedsiębiorstw, który odbywał się głównie poprzez fuzje i przejęcia. Procesy te spowodowały występowanie w niektórych przedsiębiorstwach problemów związanych ze wzrostem zadłużenia oraz integracją nabytych bądź przyłączonych firm, co w efekcie doprowadziło do dywestycji i powrotu do rdzenia działalności, tzw. core business (np. firmy Lockheed Martin, Boeing, Raytheon). Jednym z efektów koncentracji produkcji jest wzrost pozycji największych przedsiębiorstw w zamówieniach rządowych. W Stanach Zjednoczonych, w 2000 roku pięciu największych producentów zdobyło $31 \%$ rządowych kontraktów na zakupy UiSW. Udział BAE Systems (Wielka Brytania) i Thalesa (Francja) w zakupach UiSW na rynkach krajowych przez ich państwa w 2000 roku wahał się w granicach $15-20 \%{ }^{5}$.

W Stanach Zjednoczonych oraz państwach Europy Zachodniej, gdzie koncentracja kapitału i konsolidacja przedsiębiorstw przemysłu obronnego występuje najsilniej, zjawisko to przybiera dwie zasadnicze formy: - konsolidacji narodowych potencjałów produkcyjnych, • międzynarodowej współpracy kapitałowej (koncerny międzynarodowe).

Konsolidacja narodowych potencjałów produkcyjnych polega na łączeniu się w obrębie jednego państwa firm działajacych w jednej branży lub tworzeniu wielobranżowych koncernów narodowych. Przykładem konsolidacji firm w obrębie jednej branży może być amerykański przemysł lotniczy. W latach 90 . $\mathrm{XX}$ wieku liczba producentów samolotów bojowych w USA zmniejszyła się z 8 do 3 (Lockheed Martin, Boeing, Northrop Grumman). Klasycznym, wielokrotnie przytaczanym przykładem wielobranżowego koncernu narodowego jest brytyjski BAE Systems powstały z przyłączenia do Brisish Aerospace firmy GEC Marconi (elektronika) oraz Royal Ordnance (systemy artyleryjskie i amunicja ${ }^{6}$. Konsolidacja narodowych przemysłów obronnych państw Europy Zachodniej odbywa się głównie w obszarze producentów uzbrojenia i wyposażenia wojsk lądowych. W wyniku licznych fuzji i przejęć oraz powstawania spółek joint venture, jakie miały miejsce $\mathrm{w}$ tym sektorze $\mathrm{w}$ ostatnich latach, w Niemczech funkcjonują obecnie dwa wiodace przedsiębiorstwa: Rheinmetall DeTec AG oraz Krauss - Maffei Wegmann GmbH\&Co. KG, dwa w Wielkiej Brytanii: Alvis Plc i Vickers Defence Systems oraz po jednym we Francji: GIAT Industries SA i Włoszech: Consorzio Iveco - Fiat - OTO Melara ${ }^{7}$.

Konsolidacja największych firm przemysłu obronnego w USA i Europie Zachodniej szczególnie dynamicznie przebiegała w latach 90 . Obecnie daje się zauważyć ustabilizowanie sytuacji. Światowe giganty wydają się porządkować swoje struktury, pozbywając się zbędnych oddziałów. Działania konsolidacyjne są natomiast kontynuowane przez firmy średniej wielkości (znajdujące się w drugiej i trzeciej dziesiątce na liście „Defence News”) ${ }^{8}$. Nierzadko średnie firmy wykupują oddziały gigantów sektora, którzy w ramach restrukturyzacji zakresu działania dążą do uporządkowania struktur. Fuzji największych firm zbrojeniowych przeciwdziałaja również regulacje antykoncentracyjne zarówno w Stanach Zjednoczonych, jak i w Europie Zachodniej. W USA administracja przeciwstawiła się połączeniu Lockheeed Martina i Northrop Grummana (1998) oraz fuzji Grummana i Littona (2001). Przeciwko zbyt daleko idącej konsolidacji przy próbie zakupu Honeywella przez General Electric wystąpiła Komisja Europejska, która uznała, że skonsolidowana spółka miałaby zbyt duży udział na rynku silników lotniczych. Należy zauważyć, że Unia Europejska może zablokować także fuzje z udziałem przedsiębiorstw amerykańskich, w sytuacji, gdy w wyniku połączenia powstaje spółka o rocznej sprzedaży przekraczającej $250 \mathrm{mln} \mathrm{USD}^{9)}$. W grupie średnich firm przekształcenia odbywają się głównie wewnątrz poszczególnych branż: elektronicznej, rakietowej, systemów morskich i uzbrojenia wojsk lądowych. Przykładem działań w tej grupie może być przejęcie przez Rheinmetall firm KUKA Wehrtechnik GmbH i Henschel Wehrtechnik $\mathrm{GmbH}^{10)}$, czy nabycie przez grupę Saab AB firmy Celsius.

Druga, obok konsolidacji narodowych potencjałów produkcyjnych, z form koncentracji kapitału i konsolidacji przedsiębiorstw w przemyśle obronnym, jaką jest międzynarodowa współpraca kapitałowa (tworzenie koncernów międzynarodowych), zostanie scharakteryzowana szczegółowo podczas omawiania współpracy międzynarodowej w obrębie przemysłu obronnego.

\section{Współpraca międzynarodowa}

W spółpraca międzynarodowa stanowi kolejny z trendów rozwojowych i restrukturyzacyjnych w przedsiębiorstwach przemysłu obronnego na świecie. Wśród zasadniczych przyczyn występowania tego zjawiska można wskazać, podobnie jak w przypadku konsolidacji, na ogromny postęp w zakresie techniki wojskowej oraz związany z nim wzrost kosztów projektowania i produkcji wyrobów zaawansowanych technicznie do poziomu przekraczającego możliwości finansowe pojedynczych państw ${ }^{11)}$. Ponadto, jak słusznie zauważa D. George, obecnie rynki narodowe, poza Stanami Zjednoczonymi, nie zapewniają zyskowności przemysłom narodowym, powołanym do zapewnienia potrzeb obronnych poszczególnych państw. Cele, dla których rozwijana jest współpraca międzynarodowa oraz podejmowane są działania prowadzące do umiędzynarodowienia produkcji specjalnej zarówno w skali makro-, jak i mikroekonomicznej, wynikają bezpośrednio z przyczyn determinujących to zjawisko. Wśród najważniejszych z nich można wskazać na ${ }^{12)}$ :

- podział kosztów pomiędzy uczestników programów zbrojeniowych, szczególnie w zakresie badań i rozwoju,

- podział pracy i specjalizację, 
- wzrost wzajemnego poczucia bezpieczeństwa, wzajemnej zależności oraz tworzenie klimatu zaufania pomiędzy współpracującymi przedsiębiorstwami i państwami.

Przed 1990 rokiem współpraca międzynarodowa w obszarze przemysłu obronnego oparta była w głównej mierze na porozumieniach międzyrządowych w ramach NATO i EWG, co powodowało, że struktury kooperacyjne cechowały się niską elastycznością i przerostami biurokratycznymi, a w efekcie wysokimi kosztami. W latach $90 . \mathrm{XX}$ wieku główna rolę w organizowaniu kooperacji międzynarodowej przejęły przedsiębiorstwa, co znacząco poprawiło efektywność tego rodzaju współpracy. Obecnie najsilniej procesy internacjonalizacji produkcji specjalnej zachodzą w branży elektronicznej oraz lotniczo-rakietowej, najwolniej w branży pancernej oraz stoczniowej $^{13)}$.

Współcześnie analitycy SIPRI wskazują na trzy obszary, w których odbywają się procesy internacjonalizacji przemysłu obronnego: ${ }^{14}$

- pomiędzy największymi przedsiębiorstwami przemysłu obronnego Europy Zachodniej (głównie w ramach Framework Agreement),

- na poziomie transatlantyckim,

- poprzez nabycia przez firmy amerykańskie i zachodnioeuropejskie udziałów w przedsiębiorstwach przemysłu obronnego w innych państwach, głównie w kontekście kontraktów na eksport UiSW.

Współpraca międzynarodowa oraz umiędzynarodowianie się przedsiębiorstw i przemysłów obronnych mogą przyjmować dwie zasadnicze formy:

- międzynarodową współpracę produkcyjną (tworzenie międzynarodowych konsorcjów programowych),

- międzynarodową współpracę kapitałową (powstawanie koncernów międzynarodowych oraz inne formy umiędzynarodowiania się kapitałów).

Celem tworzenia międzynarodowych konsorcjów programowych jest projektowanie i produkcja określonych typów uzbrojenia, przez firmy pochodzące $\mathrm{z}$ różnych państw. Istota tego rodzaju przedsięwzięć polega na udostępnieniu przez każdego z udziałowców zasobów technologicznych, know-how, wspólnym przyczynianiu się do realizacji określonego programu oraz współpracy w zakresie marketingu i sprzedaży wspólnego produktu. Z założenia konsorcja programowe maja charakter form tymczasowych powołanych do realizacji określonego programu, jednakże w praktyce jest to często proces ewoluujaccy, prowadzacy do powstawania powiązań kapitałowych. Zaletą programów międzynarodowych jest większy wolumen zamówień (pochodzący z krajów uczestniczących w programie) oraz możliwość wykorzystania najlepszych elementów potencjału przemysłowego poszczególnych państw. Do wad zaliczyć należy: konieczność kompromisu w zakresie parametrów technicznych oraz bardziej czasochłonny i mniej efektywny proces produkcji, wynikajacy ze znacznie trudniejszej koordynacji niż w przypadku programu narodowego. Jako przykłady tej „ścieżki” współpracy międzynarodowej wskazać można m.in. programy ${ }^{15)}$ :

- Euromissile (produkcja przeciwpancernych pocisków kierowanych HOT i MILAN),
- Eurocopter (śmigłowce różnych typów, m.in. wielozadaniowa Puma, uderzeniowy Tiger),

- RAMSYS (morski system przeciwlotniczy i przeciwrakietowy RAM),

- JSF (samolot wielozadaniowy Joint Strike Fighter - Lockheed F-35),

- Eurofighter Typhoon (samolot wielozadaniowy).

Znacznie bardziej zaawansowana formą umiędzynarodowiania się przemysłu obronnego jest tworzenie koncernów międzynarodowych. Powstają one najczęściej w wyniku fuzji kilku dużych firm narodowych. Klasycznym przykładem tego trendu jest korporacja EADS (European Aeronautic Defence and Space Company), powstała 10 lipca 2000 roku w wyniku połaczenia firm: francuskiej Aerospatiale Matra Lagarde International, niemiecko-amerykańskiej DASA (DaimlerChrysler Aerospace AG) i hiszpańskiej CASA Constructionnes Aeronauticas SA). EADS jest największą firmą lotniczą w Europie i drugą, co do wielkości na świecie. Działa ona na rynku samolotów cywilnych i wojskowych, przestrzeni kosmicznej, systemów obronnych i usług z nimi związanych. W EADS zatrudnionych jest około 100 tys. pracowników w ponad 70 zakładach produkcyjnych. W 2002 roku obroty EADS wyniosły 30 mld euro, z czego $20 \%$ pochodziło z produkcji specjalnej, a $80 \%$ - z produkcji cywilnej. Grupa EADS złożona jest z pięciu firm: Airbus, Military Transport Aircraft, Aeronautics, Space, Defence and Security Systems ${ }^{16}$. EADS prowadzi intensywne działania mające na celu dalsze umiędzynarodowienie oraz koncentrację. W lutym 2001 roku EADS przejęła 26,8\% akcji fińskiego koncernu Patria Industries Oyj, a w październiku 2001 roku - 51\% akcji zakładów lotniczych PZL „Warszawa-Okęcie”17). EADS zainteresowana jest również zakupem akcji przedsiębiorstw rosyjskiego kompleksu przemysłowo-obronnego, w tym producenta samolotów myśliwskich Suhoj - firmy Irkut oraz konsorcjum Unified Aircraft Corp. mającego skonsolidować branżę lotniczą ${ }^{18)}$.

Wśród najważniejszych korzyści dla przedsiębiorstw przemysłu obronnego wynikajacych ze współpracy międzynarodowej wskazywane jest obniżenie kosztów produkcji uzbrojenia i sprzętu wojskowego, a przez to podniesienie jego konkurencyjności na rynkach zagranicznych. Uzyskanie wskazanych powyżej korzyści wynika między innymi z takich czynników, jak: wydłużenie serii produkcyjnych, unikanie powielania takich samych lub podobnych programów w różnych krajach, ułatwienia w transferze technologii oraz zniesienie ograniczeń w zakresie przepływu myśli technicznej, zmniejszenie ryzyka inwestycyjnego, obniżenie kosztów sprzedaży poprzez wykorzystanie wspólnej sieci handlowej.

\section{Prywatyzacja}

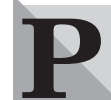

rywatyzacja stanowi kolejny $\mathrm{z}$ trendów w restrukturyzacji przedsiębiorstw przemysłu obronnego na świecie. Do początku lat 90. XX wieku własność prywatna w przemyśle obronnym państw zaliczanych do czołowych wytwórców produkcji specjalnej dominowała jedynie w Stanach Zjednoczonych. Ostatnia dekada przyniosła istotne zmiany w strukturze własności producentów uzbrojenia i wy- 
posażenia wojskowego na świecie, w szczególności zaś w Europie Zachodniej. Prywatyzacja objęła przemysły obronne w zasadzie wszystkich głównych państw zachodnioeuropejskich. Najwcześniej procesy te wystąpiły w Wielkiej Brytanii, następnie w Niemczech i krajach skandynawskich, a w końcu lat 90. nawet w państwach o silnych tradycjach etatystycznych w produkcji zbrojeniowej, takich jak Włochy, Hiszpania czy Francja ${ }^{19)}$. Analizując procesy prywatyzacyjne po 1990 roku można wskazać trzy główne obszary, w których wystąpiły procesy prywatyzacji przedsiębiorstw przemystu obronnego ${ }^{20)}$ :

- Europa Zachodnia (Francja, Włochy, Hiszpania) i Australia, gdzie prywatyzacja przemysłu obronnego była często pierwszym etapem do jego koncentracji oraz umiędzynarodowienia;

- państwa Europy Środkowo-Wschodniej, gdzie prywatyzacja przedsiębiorstw przemysłu obronnego była elementem transformacji gospodarczej;

- inne państwa o mniejszym udziale w produkcji UiSW, w których prywatyzacja powiązana była z realizacją umów offsetowych.

Prywatyzacja przedsiębiorstw przemysłu obronnego jest przedsięwzięciem o strategicznym znaczeniu dla bezpieczeństwa i obronności państwa, stąd też, jak wskazują przykłady Wielkiej Brytanii, Niemiec, Francji czy Włoch odbywa się ona pod ścisłym nadzorem agend rządowych i komisji parlamentarnych.

\section{Zmiany w strukturze prac badawczych i produkcji}

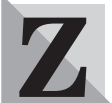

miany w strukturze prac badawczych i produkcji zostały spowodowane zmianami technicznymi (wzrost zaawansowania technicznego produkowanego uzbrojenia i wyposażenia) oraz zmniejszeniem zamówień na produkcję specjalną. Zmiany te wykazują duże podobieństwo do trendów obserwowanych w produkcji komercyjnej (odchodzenie od mało zróżnicowanych, długich serii produktów). Standardem stała się modułowość systemów uzbrojenia i sprzętu wojskowego. Najnowsze projekty wozów bojowych czy okrętów zakładają możliwość zainstalowania różnych systemów uzbrojenia, rozpoznania oraz dowodzenia na wspólnej platformie podstawowej. Niezwykle istotnym elementem w konkurowaniu na rynku uzbrojenia i sprzętu wojskowego stało się zapewnienia przez producenta serwisu przez cały okres eksploatacji sprzętu ${ }^{21)}$.

Wśród przyczyn wywołujaccych zmiany w strukturze prac badawczych i produkcji w przemyśle obronnym, wskazać można jeszcze jeden niezwykle istotny czynnik - tzw. rewolucję w wojskowości (Revolution in Military Affairs - RMA). Koncepcja rewolucji w wojskowości, której pojęcie pojawiło się w latach 90. $\mathrm{XX}$ wieku w wyniku doświadczeń z pierwszej wojny w Zatoce Perskiej, opisuje całość zmian w sposobie prowadzenia działań zbrojnych w wyniku zastosowania najnowszych osiągnięć techniki, w tym szczególnie technologii informatycznych. Zmiany te obejmuja przede wszystkim: precyzyjne rozpoznanie, identyfikację i uderzenia na wybrane cele przeciwnika, przekazywanie i analizowanie ogromnych ilości informacji w krótkim okresie, koordynowanie połączonych działań różnych rodzajów sił zbrojnych oraz wspomaganie i przyspieszenie procesu decyzyjnego dowódców (Military Decision Making Process).

W obliczu przedstawionych powyżej zmian w sposobie prowadzenia działań zbrojnych (RMA), praktycy życia gospodarczego przewidują, że w przyszłości niezwykle istotnym obszarem działalności przedsiębiorstw przemysłu obronnego staną się tzw. systemy sieciowo centryczne (network centric systems) ${ }^{22)}$. Liderem w tym obszarze są Stany Zjednoczone. Jednakże prace prowadzone są również w innych państwach. Rozwój i wdrożenie wojskowych systemów sieciocentrycznych planowane są między innymi w Szwecji ${ }^{23)}$. $\mathrm{Z}$ kolei we Francji jednym z kroków mających służyć rozbudowie możliwości technologicznych w zakresie network centric warfare była fuzja firm Snecma (silniki lotnicze) i Sagem (elektronika i telekomu-

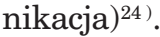

Gwałtowne zmiany w technice wojskowej25) oraz warunkach jej produkcji zdeterminowały strukturę popytu na uzbrojenie i sprzęt wojskowy. W strukturze popytu wzrosło zapotrzebowanie na środki dowodzenia i łączności, systemy informatyczne oraz nowoczesne i kompleksowe systemy uzbrojenia. Niezwykle istotnym elementem wyposażenia współczesnych sił zbrojnych stają się zintegrowane systemy sieciowe oraz bezpilotowe środki latające. Rozwijane są technologie małej wykrywalności, tzw. stealth. W złożonych cenach systemów uzbrojenia głównym składnikiem stało się oprzyrządowanie elektroniczne i wydaje się, że będzie to zjawisko długookresowe. Wynikiem tej sytuacji stała się zmiana struktury dochodów różnych sektorów przemysłu obronnego ${ }^{26)}$.

Jednym ze sposobów adaptacji przedsiębiorstw przemysłu obronnego do nowej sytuacji na rynku uzbrojenia i sprzętu wojskowego jest zmiana profilu produkcji, która przybiera formę jednej z trzech strategii $^{27)}$ :

- zmniejszenia zależności od zamówień wojskowych poprzez zwiększenie udziału produkcji cywilnej w produkcji sprzedanej ogółem,

- konwersji, czyli przestawienia części potencjału wytwórczego z produkcji specjalnej na produkcję cywilną,

- szerszego wykorzystania technologii wojskowych do celów cywilnych.

Analizując dostępne w prasie specjalistycznej case studies przedsiębiorstw przemysłu obronnego wdrażających procesy restrukturyzacji można zauważyć również tendencję do przechodzenia od produkcji wyrobów, na które spada popyt, w stronę usług na rzecz sił zbrojnych, w coraz większym stopniu korzystających z outsourcingu. Przykładem takich działań może być firma VT Group - w przeszłości czołowy brytyjski producent okrętów wojennych, która dywersyfikując zakres działania wyspecjalizowała się w usługach dla wojska ${ }^{28)}$.

\section{Zakończenie}

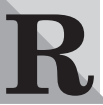
easumując, należy zauważyć, że przemysł obronny na świecie od końca lat 80 . XX wieku znajduje się w fazie głębokiej restrukturyzacji, zdeterminowanej przez zmiany polityczne, 
ekonomiczne i techniczno-technologiczne. Do zasadniczych kierunków tych zmian można zaliczyć: konsolidację przedsiębiorstw, współpracę międzynarodową, prywatyzację oraz zmiany w strukturze prac badawczych i produkcji. W ocenie autora, można oczekiwać, że wraz z rozwojem współpracy przedsiębiorstw polskiego przemysłowego potencjału obronnego z firmami zbrojeniowymi ze Stanów Zjednoczonych i państw Europy Zachodniej, w coraz szerszym zakresie polskie przedsiębiorstwa będą wdrażały przedsięwzięcia restrukturyzacyjne zidentyfikowane i scharakteryzowane powyżej, przechodząc od restrukturyzacji naprawczej typowej dla gospodarki okresu transformacji w kierunku restrukturyzacji rozwojowej charakterystycznej dla rozwiniętej gospodarki rynkowej.

mgr Andrzej Lis doktorant w Katedrze Ogólnych Problemów Zarządzania

na Wydziale Nauk Ekonomicznych i Zarzadzania Uniwersytetu Mikołaja Kopernika w Toruniu

\section{PRZYPISY}

1) Na temat procesów restrukturyzacji przedsiębiorstw polskiego przemysłowego potencjału obronnego patrz m.in: Analiza sektorowa konwersji przemystu zbrojeniowego $w$ Polsce $w$ okresie transformacji gospodarki na system rynkowy (lata 1989-1997), praca zbiorowa pod red. M. DANILUKA, INE UW, Warszawa 1999; Informacja o wynikach kontroli restrukturyzacji sektora obronnego, NIK, Warszawa 2004.

2) E.H. BOWMAN, H. SINGH, Corporate Restructuring: Reconfiguring the Firm, „Strategic Management Journal”, vol. 14, wydanie specjalne, 1993, lato, s. 6 . Na temat amerykańskiego postrzegania istoty zjawiska restrukturyzacji przedsiębiorstwa szerzej patrz: A. LIS, Restrukturyzacja przedsiębiorstwa: analiza komparatywna istoty zjawiska restrukturyzacji przedsiębiorstwa w ujęciu wybranych koncepcji amerykańskich i polskich, „Przegląd Organizacji” 2003, nr 9; Z. SAPIJASZKA, Restrukturyzacja przedsiębiorstwa: szanse $i$ ograniczenia, Wydawnictwo Naukowe PWN, Warszawa 1997, s. 24-28.

3) Por. m.in.: Arms Industry Limited, red. H. WULF, SIPRI, Oxford University Press, New York 1993, s. 162-190; I. BILL, Europejski przemyst zbrojeniowy, „Wiedza Obronna" 2001, nr 2, s. 19; M. BRZOSKA, P. LOCK, Restructuring of Arms Production in Western Europe, SIPRI, Oxford 1992, rozdz. 7, 8, 10, 11, 12; H. CHYŁKOWSKI, P. WIECZOREK, Proces restrukturyzacji krajowego przemystu obronnego w latach 1990-1997 na tle zmian zachodzacych $w$ sektorze zbrojeniowym europejskich państw NATO, Akademia Obrony Narodowej - Ministerstwo Gospodarki, Warszawa 1998, s. 16-22; D. GEORGE, Ekonomiczne $i$ polityczne implikacje umiędzynarodowienia sie przemystów obronnych [w:] Transformacja przemystu obronnego u progu XXI wieku, IV Międzynarodowa Konferencja Naukowa, VI Międzynarodowy Salon Przemystu Obronnego, Kielce 3-4. 09. 1998, Ministerstwo Skarbu Państwa - Swiętokrzyska Agencja Rozwoju Regionu, Kielce 1998, s. 29-37; K. PIĄTKOWSKI, Przysztość polskiego przemystu zbrojeniowego (Cz. II), „Nowa Technika Wojskowa” 2002, nr 2, s. 21-22; E. SKÖNS, R. WEIDACHER, Arms Production [w:] SIPRI Yearbook 2002: Armaments, Disarmament and International Security, Stockholm Peace Research Institute, Oxford University Press, New York 2002; P. WIECZOREK, Przemyst obronny państw NATO $w$ nowych realiach polityczno-wojskowych i ekonomicznych, Polski Instytut Spraw Międzynarodowych, Warszawa 1994, s. 15.

4) P. WIECZOREK, Przemyst obronny państw NATO..., s. 15.

5) E. SKÖNS, R. WEIDACHER, Arms Production [w:] SIPRI Yearbook 2002: Armaments, Disarmament and International Security, Stockholm Peace Research Institute, Oxford University Press, New York 2002, s. 326-330.

6) K. PIĄTKOWSKI, op. cit., s. 21.

7) Z. WALIGÓRA, Zachodnioeuropejska wspótpraca w dziedzinie przemystu obronnego, Departament Bezpieczeństwa Międzynarodowego MON, Wydawnictwo A. Marszałek, Warszawa 2001, s. 25.

8) Por.: T. HYPKI, Przemyst zbrojeniowy 2001, „Raport: Wojsko - Technika-Obronność" 2002, nr 12, s. 12-14; M. POLAŃCZYK, A. DOMINIK, Rywalizacja firm USA $i$ Europy trwa, „Raport: Wojsko - Technika - Obronność” 1999, nr 9; P. WIECZOREK, Konsolidacja kapitałowa polskiego przemystu obronnego $w$ latach 2002-2005, „Kontrola Państwowa" 2003, nr 3.

9) T. HYPKI, Przemyst zbrojeniowy 2000. Na świecie stagnacja, $w$ Polsce upadek, „Raport: Wojsko - Technika Obronność" 2001, nr 9, s. 10.

10) Z. RYBA, Nowe struktury europejskiego przemystu zbrojeniowego, „Wojskowy Przegląd Techniczny i Logistyczny" 2000 , nr 6, s. 35 .

11) K. PIĄTKOWSKI, op.cit., s. 21.

12) D. GEORGE, op.cit., s. 29, 32-33.

13) P. WIECZOREK, Konsolidacja kapitatowa polskiego przemystu obronnego w latach 2002-2005, „Kontrola Państwowa" 2003, nr 3.

14) E. SKÖNS, R. WEIDACHER, op.cit., s. 332.

15) K. PIĄTKOWSKI, op.cit., s. 21.

16) Szerzej patrz m.in.: EADS, „Polska Zbrojna”, 18. 01. 2004, nr 3 (365); Sita Europy, „Nowa Technika Wojskowa” 2002, nr 1, s. 57; Z. RYBA, Nowe struktury europejskiego przemystu zbrojeniowego, „Wojskowy Przegląd Techniczny i Logistyczny" 2000, nr 6, s. 36.

17) Z. WALIGÓRA, op.cit., s. 15-16.

18) P. TRAN, BAE, Finmeccanica Expand, EADS Awaits Next Move, „Defense News”, 13.12.2004, s. 8.

19) K. PIĄTKOWSKI, op.cit., s. 21.

20) E. SKÖNS, R. WEIDACHER, op.cit., s. 341.

21) K. PIĄTKOWSKI, op.cit., s. 22.

22) V.D. COFFMAN, The Defence Industry Today: Implication for Transatlantic Cooperation, wykład wygłoszony przed Rada Atlantycka oraz Centrum Reform Europejskich (Centre for European Reform) w Waszyngtonie 04.05.2000 r., INTERNET: www.lockheedmartin.com/ news/coffman5-4-00.

23) Szerzej patrz: The Implementation of Swedish Network Based Defence, „Military Technology” 2002, Special Issue: Defence and Procurement in Sweden, Vol. XXVI. Patrz także: F. REHNSTRÖM, Moving Towards Network Centric Warfare, „Military Technology”, 2002, Special Issue: Defence and Procurement in Sweden, vol. XXVI.

24) Szerzej patrz: P. TRAN, New Heft for French C4ISR, „Defense News", 01.11.2004, s. 1, 8.

25) Patrz m.in.: M. LIKOWSKI, W. ŁUCZAK, S. ZALOGA, Armia czasów wojny i transformacji, „Raport: Wojsko Technika - Obronność” 2003, nr 11, s. 4-8.

26) K. PIĄTKOWSKI, op.cit., s. 22. Patrz także: V.D. COFFMAN, op.cit.

27) P. WIECZOREK, Konsolidacja kapitałowa polskiego przemystu obronnego w latach 2002-2005, „Kontrola Państwowa" $2003, \mathrm{nr} 3$.

28) A. CHUTER, VT Group Sets Sights on U.S. Bases „Defense News", 29.11.2004, s. 17. 